\title{
Is There Any Difference in the Growth Mindset between Male and Female Students during a Pandemic?
}

\author{
Herdian $^{1}$, Fatin Rohmah Nur Wahidah', Totok Haryanto ${ }^{3}$, Akhmad Fauzan $^{4}$ \\ ${ }^{1,2}$ Faculty of Psychology, Universitas Muhammadiyah Purwokerto, Indonesia \\ ${ }^{3}$ Faculty of Economics and Business, Universitas Muhammadiyah Purwokerto, Indonesia \\ ${ }^{4}$ Faculty of Teacher Training and Education, Universitas Muhammadiyah Purwokerto, Indonesia
}

Corresponding Author: Herdian

\begin{abstract}
The pandemic that occurred until July 2021 still had an impact on the implementation of education in Indonesia. We examine how the growth mindset of students in the teaching and education faculties is during the pandemic. One hundred eighteen students participated in this study by filling out an online growth mindset questionnaire with the help of a Google form. Descriptive statistical tests were conducted to see the percentage of growth mindset, which included two dimensions, namely intelligence mindset and moral mindset. In addition, we tested the differences on both dimensions of growth mindset based on gender and GPA. The results showed that the percentage of intelligence mindset and moral mindset was at points 3 and 4 based on a Likert scale of 1 to 6 . This was in the moderate category. There is no difference in the intelligence and Moral mindset based on gender and GPA. This result proves that both men and women have the same tendency of growth mindset position.
\end{abstract}

Keywords: growth mindset, fixed mindset, gander, education school

\section{INTRODUCTION}

Pandemics that occur throughout the world impact many aspects of life, one of which is the learning process. Full online learning is recommended and even mandatory for all levels of education. However, the impact is starting to be felt until many studies report that online learning is not effective (Nurdin \& Anhusadar, 2020); this is due to its impact on learning effectiveness such as dizziness because students are required to interact online through gadgets, online learning is boring ((Mustakim, 2020). very ineffective and students ask to immediately apply faceto-face learning because online learning cannot be used as a suitable method in the teaching and learning process (Dewantara \& Nurgiansah, 2020). Other research says that online learning makes it easy for students to commit academic dishonesty (Herdian et al., 2021), as well as academic stress (Herdian \& Mildaeni, 2021). However, there are also research reports that say that online learning has proven to be effective during WFH due to the Covid-19 pandemic (Darmalaksana et al., 2020; Simatupang et al., 2020)

Many factors influence the ineffectiveness of online learning. For example, many teachers find it challenging to adapt to technology, especially teachers aged 50 years and over. As evidence that we conducted an initial study on the application of online learning, information was obtained that it was challenging to learn the technology used to support online learning. On the other hand, the teacher must also prepare a lot of creative materials and strategies in online learning so that students can learn with fun but stay focused. Similar to the results of research conducted by Ula et al., (2021), teacher mastery of technology 

pandemic?

still lacks in online learning, so that teachers become stressed in dealing with their work (Anita et al., 2021). In addition, the application of online learning is still far from the concept of e-learning, such as Interactivity, Independence, Accessibility, and Enrichment (Jaelani et al., 2020). This is the reason why online learning in Indonesia is not optimal in its application

Other factors, such as psychology in online learning, are quite a concern for researchers. A research report by Wijayanti \& Widodo (2021) states that student motivation in learning plays an important role in online learning success during a pandemic. In addition, a recent study said that one of the efforts to increase or maintain student enthusiasm for online learning during a pandemic is to increase the growth mindset (Zhao et al., 2021). Studies on growth mindset have shown that someone with a growth mindset will change or improve their situation that is considered detrimental and challenging (Liu et al., 2020). It can be concluded that in a pandemic condition that requires online learning to be considered a challenge for students to continue to follow well without any obstacles and decreased academic performance.

The term growth mindset is the individual's perspective on his abilities and intelligence (Duckworth, 2016). The concept of mindset refers to the underlying belief whether personal attributes, such as intelligence, emotions, and personality, can change (Dweck, 1999). This perspective is whether it is fixed or growth. Growth mindset is a condition where a person will assume that everything can change such as intelligence and morals. On the other hand, the fixed mindset assumes that everything is permanent and difficult to change, including intelligence and morals. The growth mindset has been widely studied to be able to have a positive impact such as school well-being and Grit (Wahidah \& Royanto, 2019), achievement (Sawitri, 2019), entrepreneurial behavior on the internet
(Dewi et al., 2020), and self-regulated learning (Putri \& Royanto, 2021)

The mindset possessed by individuals is caused by environmental factors such as parents, family, community, friends, mass media (Iskandar, 2008). In addition, other studies say that there are demographic factors that affect the growth mindset, such as gender. Like a study conducted by Macnamara \& Rupani (2017), intelligence and mindset are significant in women (but not in men), which shows that smarter women tend to have fixed mindsets. In addition, women are more susceptible to the detrimental effects of a fixed mindset in mathematical ability (Dweck, 2007). Another study said no difference in a growth mindset for women and men (Sigmundsson et al., 2020). The differences in the results of previous studies are interesting to study further with regard to gender differences in a growth mindset. In addition to the purpose of gender differences in the growth mindset, it is also important to investigate whether there are differences in the growth mindset based on the GPA

\section{MATERIALS \& METHODS Participants}

This research was conducted during the pandemic in Indonesia. Participants in this study amounted to 118 active students from the faculty of teaching and education in Indonesia. Filling out the questionnaire was done online by participants using a Google form. Willingness to become a respondent is indicated by a statement of agreement before the online filling begins. Based on table 1. Information was obtained that in the age category, this study was dominated by the age of 18 years as many as 22 students or $18.6 \%, 19$ years as many as 44 students or $37.3 \%$, and 20 years as many as 35 students or $29.7 \%$. While the participants are at least 17 years old, 24 years old, and 27 years old, each is one student or $0.8 \%$. Based on the semester category, this research was dominated by 
Herdian et.al. Is there any difference in the growth mindset between male and female students during a pandemic?

semester 2 with 64 students or $54.2 \%$ and semester 4 with 50 students or $42.4 \%$.

Meanwhile, the participants were at least from semester $8(2.5 \%)$ and semester 6 $(0.8 \%)$. Based on gender category, this study was dominated by females as many as 103 female students or $87.3 \%$, while male as many as 15 students or $12.7 \%$. Based on the last GPA category, participants with a final GPA of 3.51 - 4.00, namely 74 students or $62.7 \%$, dominated this study. GPA 2.76 - 3.50 was 43 students or $36.4 \%$, the least was GPA 2.00-2.75 as many as one student. We also collect data regarding "Are the majors taken in accordance with their passion?" obtained information that 106 students, or $89.8 \%$, said was appropriate. In comparison, as many as 12 students, or $10.2 \%$, said it was not following their passion.

\section{Measure}

The data collection tool uses a scale Implicit Theory Measures developed by Dweck et al. (1995). The intelligence mindset consists of 3 statement items, and the moral mindset consists of 3 statement items. Cronbach's Alpha Scale $(\alpha)$ for the intelligence mindset is 0.809 , and the moral mindset is 0.878 . Both scales have item-test correlation values in the range of 0.6240.704 for the intelligence mindset and $0.737-0.787$ for the moral mindset, so it can be said to have a good item-test correlation value. Scoring data using a Likert scale from 1 (true) to 6 (not true).

\begin{tabular}{|l|l|l|l|}
\hline \multicolumn{4}{|c|}{ Table 1. Participant Demographics } \\
\hline Variable & Level & Count & $\%$ \\
\hline Age & 17 & 1 & 0.8 \\
\hline & 18 & 22 & 18.6 \\
\hline & 19 & 44 & 37.3 \\
\hline & 20 & 35 & 29.7 \\
\hline & 21 & 12 & 10.2 \\
\hline & 22 & 2 & 1.7 \\
\hline & 24 & 1 & 0.8 \\
\hline & 27 & 1 & 0.8 \\
\hline Semesters & 2 & 64 & 54.2 \\
\hline & 4 & 50 & 42.4 \\
\hline & 6 & 1 & 0.8 \\
\hline Sex & 8 & 3 & 2.5 \\
\hline GPA & Male & 15 & 12.7 \\
\hline & female & 103 & 87.3 \\
\hline & $2,00-2,75$ & 1 & 0.8 \\
\hline Is Majors your passion? & $2,76-3,50$ & 43 & 36.4 \\
\hline & $3,51-4,00$ & 74 & 62.7 \\
\hline & yes & 106 & 89.8 \\
\hline & No & 12 & 10.2 \\
\hline
\end{tabular}

\section{Statistical Analysis}

We calculated the Likert scale distribution percentage based on the respondent's answer choices using descriptive analysis. Then test the Independent Samples T-Test to see the difference in intelligence mindset and moral mindset based on the demographic data obtained, namely sex and GPA.

\section{RESULT}

We conducted a percentage analysis on the answer choices given by all respondents; the data is shown in table 1. Each item's percentage was carried out for two mindset domains, namely intelligence mindset and moral mindset.

\begin{tabular}{|c|c|c|c|c|c|c|c|c|c|}
\hline \multicolumn{10}{|c|}{ Table 2. Percentage distribution of Likert scale } \\
\hline \multirow{2}{*}{ variable } & \multirow{2}{*}{ items } & \multicolumn{6}{|c|}{ percentage $(\%)$ of Likert scale } & \multirow{2}{*}{ mean } & \multirow{2}{*}{ SD } \\
\hline & & 1 & 2 & 3 & 4 & 5 & 6 & & \\
\hline \multirow[t]{3}{*}{ Intelligence Mindset } & Item 1 & 7.6 & 13.6 & 41.5 & 21.2 & 13.6 & 2.5 & 3.415 & 1.571 \\
\hline & Item 2 & 10.2 & 23.7 & 18.6 & 24.6 & 12.7 & 10.2 & 3.458 & 1.539 \\
\hline & Item 3 & 9.3 & 21.2 & 23.7 & 27.1 & 12.7 & 5.9 & 3.619 & 1.643 \\
\hline \multirow[t]{3}{*}{ Moral Mindset } & Item 1 & 13.6 & 16.9 & 23.7 & 18.6 & 14.4 & 12.7 & 3.271 & 1.167 \\
\hline & Item 2 & 8.5 & 25.4 & 19.5 & 17.8 & 16.1 & 12.7 & 3.364 & 1.483 \\
\hline & Item 3 & 11.0 & 18.6 & 19.5 & 17.8 & 14.4 & 18.6 & 3.305 & 1.349 \\
\hline
\end{tabular}

The Likert scale score used in this study is in the range of 1 to 6 . A score of 6 is the highest score which states "very like me" with the respondent's self (growth mindset). While the score of 1 is the lowest score which states "very not like me" with the respondent's self (fixed mindset). Based on table 2. It can be obtained information that in the intelligence mindset variable, the highest percentage is in the Likert range 3 and 4. It can be concluded that, in general, the intelligence mindset of our participants 

pandemic?

does not have a high enough growth mindset tendency because the Likert score is in the middle of the range. While on the moral mindset variable, the highest percentage is in the ranges 3 and 2. It can be concluded that, in general, the moral mindset in item 1 and item 3 has a "slight" tendency to fix mindset. While in item 2 , participants tend to fix mindset.

\begin{tabular}{|l|l|l|l|l|l|l|}
\hline \multicolumn{7}{|c|}{ Tabel 3. Independent Samples T-Test by Sex } \\
\hline & & Mean & SD & t & df & p \\
\hline Intelligence Mindset & male & 10.600 & 2.971 & 0.798 & 116 & 0.426 \\
\cline { 2 - 5 } & female & 9.845 & 3.480 & & & \\
\hline \multirow{2}{*}{ Moral Mindset } & male & 10.467 & 3.871 & -0.024 & 116 & 0.981 \\
\cline { 2 - 4 } & female & 10.495 & 4.334 & & & \\
\hline Note. Student's t-test.
\end{tabular}

Based on table 3 , the calculation of the study results using the independent sample T-test shows that the t-count value of gender in the intelligence mindset was obtained 0.798 with sig 0.426 ( $p>0.05$ ). This means that there is no difference in intelligence mindset based on gender. Furthermore, the t-count value of sex on the Moral mindset was obtained -0.024 with a sig of 0.981 ( $p>0.05)$ so it can be concluded that there is no difference in the Moral mindset based on gender.

\begin{tabular}{|l|l|l|l|l|l|l|}
\hline \multicolumn{7}{|c|}{ Tabel 4. Independent Samples T-Test by GPA } \\
\hline & GPA & Mean & SD & t & df & p \\
\hline \multirow{2}{*}{ Intelligence Mindset } & $3,51-4,00$ & 10.311 & 3.523 & 1.74 & 115 & 0.084 \\
\cline { 2 - 5 } & $2,76-3,50$ & 9.186 & 3.088 & & & \\
\hline \multirow{2}{*}{ Moral Mindset } & $3,51-4,00$ & 10.662 & 4.433 & 0.665 & 115 & 0.507 \\
\cline { 2 - 4 } & $2,76-3,50$ & 10.116 & 3.995 & & & \\
\hline Note. Student's t-test.
\end{tabular}

Based on table 4 , the calculation of the study results using the independent sample T-test shows that the GPA t-count value on the Intelligence mindset is 1.74 with sig 0.084 ( $p>0.05)$. Furthermore, the GPA t-count value on the Moral mindset was obtained 0.665 with a sig of 0.507 ( $>>0.05$ ) so it can be concluded that there is no difference in the Moral mindset based on GPA.

\section{DISCUSSION}

The growth mindset is essential for students because it can significantly impact students' academic performance. During this pandemic, the growth mindset has an important role. Especially when online learning is considered ineffective and adverse situations are encountered during a pandemic. The results of our study point to the growth mindset of students during the pandemic and how it differs between gender and GPA. The results of our investigation found no difference in the intelligence mindset and neither in the moral mindset for men and women. It is likewise based on the GPA owned by each student.

The results of previous studies related to growth mindset and gender found that female students were reported to have higher mathematics achievement than male students in Indonesia. This happened. Along with the increase in the growth mindset, students' mathematics achievement also increased (Kismiantini et al., 2021). However, apart from achievement, we found no difference between men and women. This research implies that both men and women have the same growth mindset. So they have no different abilities in increasing the growth mindset. This is possible because the pandemic conditions faced by students impact the same problems as previous research discussed.

Based on descriptive data, we found that students' growth mindset was at the level of points 3 and 4 on a scale of 1 to 6 . This shows that there is no high or low growth mindset tendency. So the implication of this research is that it is 

pandemic?

necessary to increase students' growth mindset so that they can carry out online learning optimally and take advantage of this adverse situation to be a challenge. This is following previous research which said that students with a growth mindset were able to change negative situations, so that students spent a lot of time changing the situation so that it was in line with their learning goals (Liu et al., 2020).

\section{CONCLUSION}

The pandemic that occurred in Indonesia until July 2021 still impacted the learning process, including in universities. The growth mindset is believed to overcome all forms of academic problems that are supposed to improve academic performance during the pandemic. No previous research has directly looked at the differences in gender and GPA in students' growth mindset. However, our results confirm that there is no gender difference in students' intelligence mindset and moral mindset. Likewise, no differences were found in the GPA results between the intelligence mindset and the moral mindset. However, we suggest to the institution that the mindset has an important role in students' academic success.

\section{Acknowledgement: None}

\section{Conflict of Interest: None}

\section{Source of Funding: None}

\section{REFERENCES}

1. Anita, T., Tjitrosumarto, S., \& Setyohadi, J. S. (2021). Stres Kerja Guru Saat Pandemi Covid-19 Ditinjau Dari Kompensasi Dan Lingkungan Kerja. Research and Development Journal of Education, 7(1), 146-157.

2. Darmalaksana, W., Hambali, R. Y. A., Masrur, A., \& Muhlas. (2020). Analisis Pembelajaran Online Masa WFH Pandemic Covid-19 sebagai Tantangan Pemimpin Digital Abad 21. Karya Tulis Ilmiah (KTI) Masa Work From Home (WFH) Covid-19
UIN Sunan Gunung Djati Bandung Tahun 2020, 1(1), 1-12.

3. Dewantara, J. A., \& Nurgiansah, T. H. (2020). Efektivitas Pembelajaran Daring di Masa Pandemi COVID 19 Bagi Mahasiswa Universitas PGRI Yogyakarta. Jurnal Basicedu, 5(1), 367-375. https://doi.org/10.31004/basicedu.v5i1.669

4. Dewi, M., Susanti, E., Susanti, R., Yenni, Z., \& Eliza, E. (2020). the Effect of Mindset Personal on Behavior of Internet Entrepreneurship Students of Universitas Putra Indonesia Yptk Padang. Sosiohumaniora, 22(1), 1-7.

5. Duckworth, A. (2016). Grit: Kekuatan Passion dan Kegigihan. Gramedia.

6. Dweck, C. S. (1999). Self-theories: Their role in motivation, personality, and development. In Self-theories: Their role in motivation, personality, and development. Psychology Press.

7. Dweck, C. S. (2007). Is Math a Gift? Beliefs That Put Females at Risk. American Psychological Association. http://www.ms.uky.edu/ ma113/s.17/cdwec kmathgift.pdf

8. Dweck, C. S., Chiu, C. yue, Hong, Y. yi, Chiu, C. yue, \& Hong, Y. yi. (1995). Implicit Theories and Their Role in Judgments and Reactions: A World From Two Perspectives. Psychological Inquiry, 6(4), 267-285. https://doi.org/10.1207/s15327965pli0604_1

9. Herdian, H., \& Mildaeni, I. N. (2021). Academic Stress On Muslim Students In Indonesia: Study On Online Learning. Revista EDUCARE-UPEL-IPB-Segunda Nueva Etapa 2.0, 25(1), 224-239.

10. Herdian, H., Mildaeni, I. N., \& Wahidah, F. R. (2021). "There are Always Ways to Cheat" Academic Dishonesty Strategies During Online Learning. Journal of Learning Theory and Methodology, 2(2), 60-67.

11. Iskandar. (2008). Metodologi Penelitian Pendidikan Dan Sosial (Kualitatif Dan Kuantitatif). Gaung Persada Press.

12. Jaelani, A., Fauzi, H., Aisah, H., \& Zaqiyah, Q. Y. (2020). Penggunaan media online dalam proses kegiatan belajar mengajar pai dimasa pandemi covid-19 (Studi Pustaka dan Observasi Online). Jurnal IKA PGSD (Ikatan Alumni PGSD) UNARS, 8(1), 1224. 
Herdian et.al. Is there any difference in the growth mindset between male and female students during a pandemic?

13. Kismiantini, E. P. S., Pierewan, A. C., \& Montesinos-López, O. A. (2021). Growth Mindset, School Context, And Mathematics Achievement In Indonesia: A Multilevel Model. Journal on Mathematics Education, 12(2), 279-294.

14. Liu, W., Yue, X.-G., \& Tchounwou, P. B. (2020). Response to the COVID-19 Epidemic: The Chinese Experience and Implications for Other Countries. International Journal of Environmental Research and Public Health, 17(7), 2304. https://doi.org/10.3390/ijerph17072304

15. Macnamara, B. N., \& Rupani, N. S. (2017). The relationship between intelligence and mindset. Intelligence, 64, 52-59.

16. Mustakim, M. (2020). Efektivitas pembelajaran daring menggunakan media online selama pandemi covid-19 pada mata pelajaran matematika. Al Asma: Journal of Islamic Education, 2(1), 1-12.

17. Nurdin, N., \& Anhusadar, L. (2020). Efektivitas Pembelajaran Online Pendidik PAUD di Tengah Pandemi Covid 19. Jurnal Obsesi : Jurnal Pendidikan Anak Usia Dini, $5(1)$, 686. https://doi.org/10.31004/obsesi.v5i1.699

18. Putri, Y. B. A., \& Royanto, L. R. M. (2021). Growth mindset, instructors scaffolding, dan self-regulated learning pada pembelajaran jarak jauh selama pandemi COVID-19. Jurnal Psikologi Ulayat. https://doi.org/10.24854/jpu167

19. Sawitri, N. D. (2019). Memberikan Pujian yang Tepat menurut Growth Mindset. Adi Widya: Jurnal Pendidikan Dasar, 2(2), 5160.

20. Sigmundsson, H., Haga, M., \& Hermundsdottir, F. (2020). Passion, grit and mindset in young adults: Exploring the relationship and gender differences. New Ideas in Psychology. https://doi.org/10.1016/j.newideapsych.2020 .100795

21. Simatupang, N. I., Sitohang, S. R. I., Situmorang, A. P., \& Simatupang, I. M. (2020). Efektivitas pelaksanaan pengajaran online pada masa pandemi covid-19 dengan metode survey sederhana. Jurnal Dinamika Pendidikan, 13(2), 197-203.

22. Ula, S., Afifa, A. N., \& Azizah, S. A. (2021). Pengaruh Penggunaan Teknologi Di Masa Pandemi Covid-19 Terhadap Hasil Belajar Pada Mata Pelajaran Biologi Di Man 2 Jember. ALVEOLI: Jurnal Pendidikan Biologi, 2(1), 54-66.

23. Wahidah, F. R., \& Royanto, L. R. M. (2019). Peran Kegigihan Dalam Hubungan Growth Mindset Dan School Well-Being Siswa Sekolah Menengah. Jurnal Psikologi TALENTA, $\quad 4(2), \quad 133$. https://doi.org/10.26858/talenta.v4i2.7618

24. Wijayanti, N., \& Widodo, S. A. (2021). Studi Korelasi Motivasi Belajar terhadap Hasil Belajar Matematika Selama Daring. Journal of Instructional Mathematics, 2(1), 1-9.

25. Zhao, H., Xiong, J., Zhang, Z., \& Qi, C. (2021). Growth Mindset and College Students' Learning Engagement During the COVID-19 Pandemic: A Serial Mediation Model. Frontiers in Psychology, 12(February), 1-10. https://doi.org/10.3389/fpsyg.2021.621094

How to cite this article: Herdian, Wahidah FRN, Haryanto $\mathrm{T}$ et.al. Is there any difference in the growth mindset between male and female students during a pandemic? International Journal of Research and Review. 2021; 8(7): 245-250. DOI: https://doi.org/10.52403/ijrr. 20210734 